University of Louisville

ThinkIR: The University of Louisville's Institutional Repository

College of Arts \& Sciences Senior Honors

Theses

College of Arts \& Sciences

$5-2015$

\title{
James Wilson and Anglo-American customary constitutionalism.
}

Sean Allen Southard

University of Louisville

Follow this and additional works at: https://ir.library.louisville.edu/honors

Part of the United States History Commons

\section{Recommended Citation}

Southard, Sean Allen, "James Wilson and Anglo-American customary constitutionalism." (2015). College of Arts \& Sciences Senior Honors Theses. Paper 33.

http://doi.org/10.18297/honors/33

This Senior Honors Thesis is brought to you for free and open access by the College of Arts \& Sciences at ThinkIR: The University of Louisville's Institutional Repository. It has been accepted for inclusion in College of Arts \& Sciences Senior Honors Theses by an authorized administrator of ThinkIR: The University of Louisville's Institutional Repository. This title appears here courtesy of the author, who has retained all other copyrights. For more information, please contact thinkir@louisville.edu. 
James Wilson \& Anglo-American Customary Constitutionalism

By

Sean Allen Southard

Submitted in partial fulfillment of the requirements

for Graduation summa cum laude

University of Louisville

March 2, 2015 


\section{Introduction}

In 1774, James Wilson publicly posed a question regarding the nature of British liberty: "Is British freedom denominated from the soil, or from the people of Britain?" He asked, "If from the latter, do they lose it by quitting the soil? Do those, who embark, freemen, in Great Britain, disembark slaves, in America?" Wilson wrote these words privately in a 1768 pamphlet titled "Considerations on the Nature and Extent of the Legislative Authority of the British Parliament" and in it, he denied British Parliamentary authority to legislate for the North American British Colonies in all circumstances. Wilson was one of the first to argue that no colonist granted political or constitutional authority to Parliament. In the second decade of the twenty first century, one could think that a study of James Wilson and the American Revolution is passé. Historians have discussed Wilson's ideology at length over the years and have placed him in the minority of the Revolutionaries and delegates at the 1787 Constitutional Convention due to his ardent defense of a national constitutionalism and his adherence to Natural Law. However, this essay argues that the time is ripe for an examination of Wilson's political and constitutional theory in light of new research on the origin and promise of the Revolution and how American Whigs viewed the separation from Great Britain. Wilson's political speeches, papers, and writings during the American Revolution represent an indictment of the British Parliament rooted in the Anglo-American customary constitution that the Whigs traced back to Sir Edward Coke (1552-1634) and the 1688 Glorious Revolution. This Anglo-American constitution differed significantly from the one claimed by a sovereign and supreme Parliament during the revolutionary crisis. While most monographs on Wilson's political and constitutional thought focus on his Scottish Enlightenment and Natural Law influences, this essay asserts the

\footnotetext{
${ }^{1}$ James Wilson, The Collected Works of James Wilson, eds. Mark David Hall \& Kermit Hall, (Indianapolis, IN: Liberty Fund, 2007), 16.
} 
equal importance of the Anglo-American customary constitution in shaping Wilson's political thought for popular elections during the Constitutional Convention. As demonstrated in the third section of this essay, Wilson's position at the Constitutional Convention of 1787 gave him a platform to incorporate the Anglo-American customary constitution in the law of the land.

\section{Historiography}

\section{James Wilson}

Historical literature written about Wilson's influence during the American Revolutionary and Constitutional eras is not as wide and deep as it is for other figures from the revolutionary and founding eras. Those interested in the study of Colonial Whigs should note, however, that several informative monographs on Wilson and his life exist, as well as specific works that address his political ideology and the ideas embodied in his 1791-92 Lectures on the Law that he delivered at the University of Pennsylvania School of Law.

In 1956, historian Charles Page Smith published the most expansive biography of Wilson. $^{2}$ The Smith biography provided an extended look at the life of Wilson from his childhood in Scotland, his reduced stature in debtor's prison, and the events surrounding his death. Wilson scholar Mark David Hall hailed Smith's book as the ultimate biography of Wilson's life, but some scholars believe that Smith's depiction of Wilson's life in Scotland to contain embellishments. For example, in 2013 Martin Clagett penned an essay that corrected some of Smith's errors in light of new scholarship that appeared after Smith completed his book. Clagett suggested that relatively little biographical information exists on the formative years of Wilson's life and cautioned readers that to according to his reading of Wilson's life, Smith drew

\footnotetext{
${ }^{2}$ Charles Page Smith, James Wilson, Founding Father, 1742-1798 (Chapel Hill, NC: University of North Carolina Press, 1956).
} 
from few letters in an expansive way that might call the entire section about Wilson's early childhood into question. $^{3}$

Mark David Hall researched the legal philosophy of Wilson in The Political and Legal Philosophy of James Wilson, 1742-1798 and published his work in 1996. Hall maintained that Wilson's engagement with the Scottish Enlightenment influenced his ideas about morality and national government. Hall called his book the first systematic study of Wilson's moral epistemology and he provided a helpful historiography on Wilson. Hall criticized Jean Marc Pascal's The Political Ideas of James Wilson for disorganization and a lack of analysis while he argued that a discussion of the connections between Wilson's political activity and theory was absent from Geoffrey Seed's James Wilson, Founding Father. ${ }^{4}$ Hall relied upon the law lectures to defend his thesis and his organized approach revealed how Wilson the legal philosopher viewed the role of the individual in the pursuit of truth and law in pursuit of morality. Hall dedicated a couple of chapters to Wilson's participation in the Constitutional Convention and his understanding of the people that inhabited the United State existed as a single entity. ${ }^{5}$ Hall's book served as an impressive means to understanding the Natural Law and Scottish Enlightenment influences on Wilson's thought.

James H. Read contrasted the political philosophies of Alexander Hamilton, James Madison, Thomas Jefferson, and Wilson in Power Versus Liberty: Madison, Hamilton, Wilson, and Jefferson. In this work, Read stated that Wilson's "greatest contribution came at the Federal

\footnotetext{
${ }^{3}$ Martin Clagett, "James Wilson-His Scottish Background: Corrections and Additions," Pennsylvania History: A Journal of Mid-Atlantic Studies 79 (2012): 151.

${ }^{4}$ Mark David Hall, The Political and Legal Philosophy of James Wilson, 1742-1798, (Columbia, MO: University of Missouri Press, 1997), 4.

5 "The people" defined as white, male, property-owners over the age of 21.
} 
convention, where his influence in shaping the final document was "second only to Madison's."6 Read's study of Wilson revealed an ideology that included nationalistic ideas akin to those of Hamilton and democratic ones akin to Jefferson. When compared to Madison, Wilson had a weak record on civil liberties due to his stalwart opposition to a bill of rights in the Constitution. However, it ought to be noted that Madison's support for a bill of rights was a result of his political maneuvering to build consensus for the Constitution's adoption. Regardless of this point, Read argued that Wilson's poor record on civil liberties made "Wilson's keenest insights only partial truths. This applies to the problem of reconciling the power of government with the liberty of citizens." According to Read, the fundamental argument made by Wilson was that the constitutional argument of the American Revolution placed the sovereignty in the people, not in either the state or national governments, but that this argument was not enough to protect liberty. ${ }^{8}$ This argument is flawed, as it does not give a full understanding of Wilson's own disposition that elections were superior to a bill of rights in protecting civil liberties.

A University of Louisville master's thesis authored by Bradley Jay Caffee is one of the most recent pieces of scholarship about Wilson. Caffee argued that Wilson espoused a "progressive" view of the revolutionary and constitutional experiences and that his ideas held a special place in American thought for laying a foundation for "moral and civil progress."9 Although Wilson maintained a view of humanity that allowed for improvement, it is debatable as to whether or not "progressive" is the proper term to describe Wilson during the Revolution and Constitutional Convention. The word "progressive" contains many connotations including that

\footnotetext{
${ }^{6}$ James Read, Power Versus Liberty: Madison, Hamilton, Wilson, and Jefferson (Charlottesville, VA: University Press of Virginia, 2000), 92.

${ }^{7}$ Ibid., 115.

${ }^{8}$ Ibid.

${ }^{9}$ Bradley Jay Caffee, “James Wilson: Progressive Constitutionalist," (M.A. Thesis - University of Louisville, 2003), 4.
} 
of the progressive reform movement of the 1920's and of contemporary liberalism. By the time that Wilson delivered his law lectures at the University of Pennsylvania, he may have realized that the ideas embodied in the revolutionary ideology were progressive in the sense that they were forward-looking. However, it is important to try to suppress the temptation to write history with the mindset of the twentieth and twenty-first centuries and instead to understand the Revolutionary crisis as the American Whigs, and Wilson, understood it. Caffee dedicated an entire chapter to Wilson's work during the Revolution, but only briefly discussed Wilson's ideas in the context of the Anglo-American customary constitution. Wilson's 1768 pamphlet on parliamentary authority in the colonies voiced the intention of the revolutionaries to maintain British liberty as it had existed traditionally in the colonies and abstained from defining a different liberty for a new age.

The Revolutionary \& Constitutional Eras

Historians have always been interested in the values and ideas of the Revolutionary and Constitutional generations. Immediately after the end of the Revolution, a Massachusetts royalist by the name of Peter Oliver wrote The Origin and Progress of the American Rebellion. ${ }^{10}$ In using the word "rebellion," Oliver revealed his position on the nature of the controversy between the British Empire and her colonies and portrayed Massachusetts Royal Governor Thomas Hutchison, a favorite target of many Whigs, in a sympathetic light. Although Oliver's account makes for an interesting read, the modern study of the Revolution and Constitution arrived in the nineteenth century with the publication of George Bancroft's multivolume history. Then in the economic uncertainty that appeared in the first decades of the twentieth century, economic despair coincided with the advent of determinist historians who forced the

\footnotetext{
${ }^{10}$ Peter Oliver, Peter Oliver's Origin \& Progress of the American Rebellion: A Tory View, Douglass Adair \& John A. Shutz, eds., (Redwood City, CA: Stanford University Press, 1961).
} 
revolutionary and constitutional experience through a narrow economic lens. One of the best examples of a historical work that falls under this category is Charles Beard's 1913 book $A n$ Economic Interpretation of the Constitution of the United States. The desire of Beard and other progressive historians of the era for social and economic reform programs shaped their view that economic factors motivated the movements for the Revolution and Constitution. ${ }^{11}$ Wilson suffered numerous financial difficulties and was consistently in debt through his life because of his investments in western land speculation. As Caffee pointed out, if Beard had studied Wilson's poor financial planning alongside his support for popular elections, he might have realized that at least one figure at the Convention went entirely against his argument that the sole purpose of the Constitution was to benefit the upper class. ${ }^{12}$

In the period that followed the entry of the United States into the Second World War, a group of new historians began to pick away at the economic arguments of progressive era historians. The study of the American Revolution experienced its own revolution with the publication of Bernard Bailyn's 1967 Ideological Origins of the American Revolution. ${ }^{13}$ This book was the product of Bailyn's analysis of a study of pamphlets published during the Revolution. He emphasized the importance of taking authors of revolutionary pamphlets at their word, and interpreted the American Revolution as being motivated by a flood of opposition thought from England over the course of the seventeenth century. According to Bailyn, the Whigs, or the oppositionist group, were opposed to taxation without representation and were hell-bent on maintaining the liberties their forefathers held in England. Bailyn credited the

\footnotetext{
${ }^{11}$ Roy N. Lokken, "The Political Theory of the American Revolution: Changing Interpretations," The History Teacher 8 (1974): 94.

12 Caffee, 8.

${ }^{13}$ Bernard Bailyn, The Ideological Origins of the American Revolution (Cambridge, MA: Harvard University Press, 1967).
} 
philosophies of social contract thinkers, Enlightenment philosophes, and English common law lawyers as factors that shaped the thought of American Revolutionary leaders, but he held that a tradition of British oppositionist politics bound the group together. A year later he published The Origin of American Politics in which he called political papers and pamphlets the best primary sources for understanding the thought of American Whigs, as they provided "clarity" to the "political responses of the time."14 He affirmed his earlier assertion in Ideological Origins that a comprehensive view of the colonial mind could only be understood through the opposition ideology that trickled into the colonies during the seventeenth and eighteenth centuries and offered Cato's Letters as an example of one work that shaped colonial logic. ${ }^{15}$

Bailyn also argued that the goal of the American Revolution was not to create new social relationships and institutions, or "a world entirely new" as Alexis de Tocqueville stated, but that the central goal of the American Revolution was the "preservation of political liberty," as the colonists had historically understood the word "liberty." It It is important to remember that the context of the 1960's shaped Bailyn's scholarship, though in a different way from that of the progressive school that preceded him. His argument that the American Revolution did not seek to develop new social relationships ought to be viewed in the context of the social change in which he wrote. Bailyn's critics are quick to raise this point, and are correct to do so as long as they maintain that the issue of historiographical context extends to all historians. Regardless, Bailyn's work is important for igniting a new generation of scholarship on the revolutionary and the constitutional experience, and his scholarship allowed colonials to speak for themselves through their own pamphlets, speeches, and papers.

\footnotetext{
${ }^{14}$ Bailyn, The Origin of American Politics (New York, NY: Knopf, 1968), 19. ${ }^{15}$ Ibid., 40-45.

${ }^{16}$ Alexis de Tocqueville, Democracy in America, Volume 1, James T. Schleifer, ed., (Indianapolis, IN: Liberty Fund, 2010), 14; Bailyn, Ideological Origins, 19.
} 
A wave of scholars reacted to Bailyn's work and strengthened his interpretation. The new school earned the title of a "republican consensus" for its insistence that power of ideas was the catalyst of the Revolution. ${ }^{17}$ Indeed, J.G.A. Pocock's 1975 book, The Machiavellian Moment: Florentine Political Thought and the Atlantic Republic Tradition, traced values of republicanism and virtue back to Machiavelli's Discourses on Livy in order to argue that country politicians and landed aristocracy who lived in the Virginia colony inherited those thoughts. Pocock agreed with Bailyn in the importance of Cato's Letters on the transmission of fears about the encroachments of royal power on the liberty of the people to British North America. Added to this fear was the perception of corruption, which dominated the ideas of Whig leaders who believed that George III, royal minsters, and Parliament waged a war against colonial liberty. ${ }^{18}$ Gordon S. Wood bolstered the foundation created by Bailyn and agreed in The Creation of the American Republic that the key to understanding the American Revolution was through the lens of oppositionist political theory. ${ }^{19}$ Wood emphasized, too, the importance of Cato's Letters to American Whigs. The publication of books with the republican-consensus is still being conducted today. Jack N. Rakove published the Pulitzer Prize-winning Original Meanings in 1997, a book that walked readers through the happenings of the Constitutional Convention and focused on the role of James Madison as he solidified support for the document. Rakove made

${ }^{17}$ Colin Gordon, "Crafting a Usable Past: Consensus, Ideology, and Historians of the American Revolution," The William and Mary Quarterly 46 (1989): 672.

${ }^{18}$ J. G. A. Pocock, The Machiavellian Moment: Florentine Political Thought and the Atlantic Republic Tradition (Princeton, NJ: Princeton University Press, 1975), 474.

${ }^{19}$ Gordon S. Wood, The Creation of the American Republic, 1776-1787 (Chapel Hill, NC: University of North Carolina Press). 
his way through the arguments at the convention to find "the middle ground" between the "ideas or interests" feud that emerged between historians of this area of United States history. ${ }^{20}$

Legal history is a growing field within early colonial and United States history, although its rightful place in the conversation about the ideas and values of the American Revolution is murky. Legal historian and New York University School of Law Professor John Phillip Reid took an interest in the legal foundations of the American Revolution and Constitution after reading that Bailyn believed that "law was irrelevant to the making of the Revolution." 21 Reid argued that law was indeed relevant in his four-volume Constitutional History of the American Revolution, but his scholarship has not received the widespread recognition it deserves. Reid is one of the most prolific authors on the study of the American Revolutionary era as his Constitutional History spans the authorities of rights, taxation, legislation, and law. The volumes on authorities of law and legislation provided critical analysis in understanding the Colonial Whig arguments levied at Parliament and the King. He has also completed a monograph on the subject of liberty in the eighteenth century.

In his 1981 book, In Defiance of the Law: The Standing Army Controversy, the Two Constitutions, and the Coming of the American Revolution, Reid stated that the field of the American Revolution cannot be understood as a misinterpretation of a single constitution, but as a crisis of two constitutions: one of traditional customary colonial relations to the monarchy and parliament and another, newer constitution of parliamentary supremacy. ${ }^{22}$ Reid applied this idea

\footnotetext{
${ }^{20}$ Jack N. Rakove, Original Meanings: Politics and Ideas in the Making of the Constitution (New York, NY: Vintage Books, 1997), 15.

${ }^{21}$ Hendrick Hartog \& William E. Nelson, Law as Culture and Culture as Law: Essays in Honor of John Phillip Reid (Madison, WI: Madison House Publishers, 2000), 5.

${ }^{22}$ John Phillip Reid, In Defiance of the Law: The Standing Army Controversy, The Two Constitutions, and the Coming of the American Revolution (Chapel Hill, NC: University of North Carolina Press, 1981).
} 
of two constitutions to the deployment of a standing army in Boston and demonstrated that colonial references to the "constitution" fell on the deaf ears of King George III, the royal ministry, and Parliament. With the passage of the 1766 Declaratory Act, the disciples of parliamentary command assured themselves of supremacy in in all legislative matters. Most colonials acknowledged parliamentary supremacy over the monarch, but they did not respect a doctrine of parliamentary supremacy that exceeded the traditional limits of authority towards the colonies and provided justification for the deployment of a standing army in Boston Harbor. On the point of the influence of natural law on the Revolution's political theory, Reid reiterated another one of his arguments: that the arguments about the constitution during the Revolution were "[m]ore Cokean than Lockean, more common law than natural law." 23 Reid asserted that the driving forces behind the Revolution were law, constitutionalism, and the birthrights of free men in the British Empire.

The accusation that earlier historians supplanted Coke's influence with Locke's on the Revolutionary generation is not new. David Thomas Konig called Coke's legal theory on common-law constitutionalism "an article of faith" in forming Madison's understanding of constitutionalism two hundred years later. ${ }^{24}$ Other scholars have remarked that Coke's influence extended to several leaders of the Revolution including James Otis, Samuel and John Adams, John Dickenson, and James Wilson. ${ }^{25}$ Charles Mullet called James Wilson the revolutionary leader that was most familiar with Coke. ${ }^{26}$

\footnotetext{
${ }^{23}$ Reid, Defiance, 35.

${ }^{24}$ David Thomas Konig, "James Madison and Common-Law Constitutionalism," Law and History Review 28 (2010): 511.

${ }^{25}$ Charles F. Mullet, "Coke and the American Revolution," Economica 38 (1932): 468-470.

${ }^{26}$ Ibid., 470. See also Ellis Sandoz, The Roots of Liberty: Magna Carta, Ancient Constitution, and the Anglo-American Tradition of Rule of Law (Indianapolis, IN: Liberty Fund, 2008).
} 
Reid conducted a linguistic study of the word "liberty" in a thin volume titled, The Concept of Liberty in the Age of the American Revolution. ${ }^{27}$ To the seventeenth and eighteenth century colonial, liberty was procedural in nature and grounded in processes located in the legal system. Reid named a few sources for this liberty, including “custom, original contract, constitutional principle, ownership, inheritance, and, to a minor extent, natural law." ${ }^{28}$ This book modified the ideas of Bailyn, who described the Revolution as the offspring of oppositionist thought and those who placed more emphasis on the liberty of the European Enlightenment. Reid contended that the chief motivation of the American Revolution was the infraction upon this legal or political liberty embodied in the common law constitutionalism that colonials and their ancestors had known for centuries in the colonies. The threat to liberty came from within and from outside the colonies. The eighteenth century mind believed that if order and liberty were left unbalanced that liberty could quickly slip into license, a corruption of true liberty. Yet this balance was tenuous: an excess of order could slip into an arbitrary exercise of power and power always coveted and encroached upon liberty's territory. This external threat found its home in rhetoric referring to arbitrary government and slavery. ${ }^{29}$

Reid's volume on the authority of law summarized the legal arguments that led to the divergence of constitutional theory that occurred between Parliament and the North American British Colonies. Parliament sought a parliamentary solution to the colonial problem. Had King George granted royal sanction to the colonial assemblies and permitted co-equal status with

\footnotetext{
${ }^{27}$ Reid, The Concept of Liberty in the Age of the American Revolution (Chicago, IL: University of Chicago Press, 1988).

${ }^{28}$ Ibid., 23.

${ }^{29}$ Ibid., 32. Reid referred to the eighteenth century notion of "civil liberty" as a means of understanding the liberty that American Whigs referenced in their pamphlets and speeches. On the word "slavery," Reid pointed out the clear contradiction in the colonial claim about political enslavement and the use of race-based slave labor in the South.
} 
Parliament, he increased the power of the throne and diminished parliamentary power. ${ }^{30}$

Completing the logic presented by Parliament's rejection of a solution preferred by the colonies revealed a fear held by many colonists: the doctrine of parliamentary supremacy placed the Britons in England above the Britons in America. ${ }^{31}$ This volume detailed how the liberty issue raised by the colonists was tied to other matters of security and representation. All of these issues appeared in the argument that denied parliamentary supremacy over colonial affairs. In the volume on the authority of legislation in Constitutional History, Reid offered a new argument into academic discussion regarding the origin of the controversy between the colonies and Parliament. ${ }^{32}$ This volume differed from the view that portrayed the Revolution as the result of a tax disagreement and took the position that the real rub appeared when Parliament forced its right to legislate to the front of the crisis. ${ }^{33}$ He lobbed a series of criticisms at other historians in the field for having misplaced and focused on arguments provided through John Locke, social contract, and natural law theory. According to Reid, there is little to no evidence that those arguments appealed to Colonial Whigs; he argued that such arguments ought to be rejected and replaced with arguments and ideas grounded in the British constitution. ${ }^{34}$ Furthermore, Reid argued that the Whigs worried their parliamentary counterparts when the colonists rejected parliament's position and looked to King George for redress. To the observer in England, it looked as if the American Whigs were asking to relitigate the constitutional arrangement of the Glorious Revolution of 1688.

\footnotetext{
${ }^{30}$ Reid, Constitutional History of the American Revolution: The Authority of Law (Madison, WI: University of Wisconsin Press, 1993), 166-168.

${ }^{31}$ Ibid., 76-78.

32 Jack P. Greene, "John Phillip Reid and the Reinterpretation of the American Revolution," in Law As Culture \& Culture As Law, 55.

${ }^{33}$ Reid, Constitutional History of the American Revolution: The Authority to Legislate (Madison, WI: University of Wisconsin Press, 1991), 5.

${ }^{34}$ Ibid.
} 
Though on its face Reid's argument about the nature of the Revolutionary controversy suggested that he agreed with the republican consensus forged by Bailyn and his disciples, some scholars believe that his work departed from the consensus school in a significant way. Jack P. Greene offered a possible reason for the lack of acceptance of Reid's historical scholarship in that Reid's argument "suggests that that the revolution that occurred between 1760 and 1783 was a British revolution that has to be understood as an episode in British imperial history."35 This reason might be why Reid's scholarship has not received a warm reception - as he argued against those who understood the American Revolution as a uniquely American event. To simplify what Reid argued across the body of his work, the Revolution was the product of an incredibly British legal and constitutional crisis that, hinging on different definitions of the same words, ultimately became too legal for the two sides to reach an amicable conclusion.

Historians such as Bailyn, Wood, and Reid are incredibly skilled in their ability to provide a vast amount of content with a stunning amount of primary source material. However, these historians risk leaving the human element out of the historical narrative. Peter Hoffer discussed this point extensively in The Salem Witch Trials: A Legal History and called for historians to be wary of equating change with a sudden burst of social and cultural momentum due to abstract ideas. Hoffer remarked that, "if, in the end, we regard complex human beings as mere pawns of powerful cultural forces, [historians] lose all sense of the importance of choice and contingency."36 Indeed, historians are called to tell how change occurred and in order to describe social change, some historians lose sight of individual actors that move the wheels of history. However, according to Bailyn, one of the difficult aspects of historical writing is

\footnotetext{
${ }^{35}$ Greene, Law as Culture and Culture as Law, 56.

${ }^{36}$ Peter Charles Hoffer, The Salem Witch Trials: A Legal History (Lawrence, KS: University Press of Kansas, 1997), 6.
} 
striking a proper balance between viewing historical change from the vantage point of the twenty-first century with the motivations rooted in the context of the time that historians are analyzing. ${ }^{37}$ To this end, this study of James Wilson seeks to place his constitutional arguments of the American Revolution in the wider contextual history of the Revolutionary and Constitutional eras.

\section{Overlooking Wilson}

Several reasons exist why historians and political scientists overlook Wilson in their studies of the late eighteenth century. Chief among those reasons is the lack of primary sources available to those interested. Some personal papers lie at the University of Pennsylvania, but not many. A survey of Thomas Jefferson's papers revealed that Wilson wrote to Jefferson a few times and mostly about mundane matters, such as to suggest the appointment of a fellow Pennsylvanian for a clerical position. ${ }^{38}$ Hamilton's papers contained a letter that Hamilton wrote to Wilson in which he solicited the latter's support in building unanimous consensus for George Washington's election as president. ${ }^{39}$ Apart from that letter, Hamilton mentioned Wilson numerous times in salary reports for the national government and once to James Madison, where he penned that "Wilson [was] evidently out of the question" in terms of his qualifications for a position in the executive branch being created at that time. ${ }^{40}$ Such letters are not that helpful in revealing what Wilson's peers thought about his legal and Whig thought. It is known, however, that John Adams lauded Wilson's intellectual capacities to his wife Abigail in a letter and that

\footnotetext{
${ }^{37}$ See Bailyn, "Context in History" in Sometimes an Art: Nine Essays on History (New York, NY: Knopf, 2015).

38 James Wilson to Thomas Jefferson, August 13, 1790, in The Papers of Thomas Jefferson, ed. Julian P. Boyd (Princeton, NJ: Princeton University Press, 1950), Vol. 17, 354.

${ }^{39}$ Alexander Hamilton to James Wilson, January 25, 1798, in The Papers of Alexander Hamilton, eds. Harold Syrett, Jacob Cooke (New York, NY: Columbia University Press, 1961), Vol. 5, 247-249.

${ }^{40}$ Alexander Hamilton to James Madison, Nov. 23, 1788, Vol. 5, 236-237.
} 
George Washington thought Wilson so qualified in terms of legal skills that he forced his nephew Bushrod to study law under him. ${ }^{41}$

The entirety of Wilson's political and philosophical writings and speeches are contained in two volumes compiled in 2007 by biographer Mark David Hall and scholar Kermit L. Hall. This edition stands as the most comprehensive edition of Wilson's writings to date and includes recently discovered manuscript notes in the law lectures that Wilson delivered in the 1790's. Other factors contributing to Wilson's lower status among the founders of the United States might be due to his diminished reputation near the end of his life. Although he rose to become an Associate Justice of the United States Supreme Court, Wilson increasingly dealt with a staggering amount of debt that landed him in several debtors' prisons. ${ }^{42}$ Hall also attributed Wilson's "relative obscurity" to the fact that he sat on the Supreme Court "at a time when there was little business before that body. $" 43$ In addition, the field of historical scholarship regarding the American Revolution by and large concerns itself with the triumph of Jeffersonian idealism over Federalist thought. However, consensus exists among historians and political scientists that the shadows of Washington, Hamilton, Jefferson, and Madison have eclipsed Wilson's legacy. ${ }^{44}$

\footnotetext{
${ }^{41}$ Hall, The Political Philosophy of James Wilson, 13, 19.

${ }^{42}$ Hall, Collected Works, xvi, xxv. According to Hall, Wilson is "the only justice of the Supreme Court imprisoned for debt." Wilson was imprisoned for his debts in New Jersey and South Carolina. He was released from jail in South Carolina, but soon caught malaria and died a year later. For the history of debt imprisonment in the United States see Peter J. Coleman, Debtors and Creditors in America: Insolvency, Imprisonment for Debt, and Bankruptcy, 1607-1900, (Madison, WI: Wisconsin Historical Society Press, 1974); Bruce H. Mann, Republic of Debtors: Bankruptcy in the Age of American Independence, (Cambridge, MA: Harvard University Press, 2002).

${ }^{43}$ Hall, “James Wilson,” America's Forgotten Founders, eds. Hall \& Gregg (Wilmington, DE: 2011), 32.

${ }^{44}$ Ibid., 167. The poll conducted by Hall and Gregg among historians and political scientists ranked Wilson as the number one most forgotten founder, and he earned 214 points, which placed him 62 points above the second-most forgotten founder, George Mason.
} 
A tendency also exists for the modern mind and popular culture to reduce complicated subjects to simple binary comparisons. Numerous examples of this problem exist including the differing visions of the republic offered by Hamilton and Jefferson, the positions taken during the ratification of the Constitution by the Federalists and Anti-Federalists, and contemporary debates that occur between Democrats and Republicans. More often people situate themselves and their ideas along a spectrum. This problem of binary history leads to a non-nuanced view of the past and of figures that might not fit into one faction or another. Others might suggest that Wilson's Natural Law influences are responsible for his political thought - this essay does not dispute that. It would be an error to reduce Wilson to the product of one intellectual influence whether those influence were rooted in the Anglo-American customary constitutionalism, the Scottish Enlightenment, or the body of Natural Law. Page Smith called Wilson "an enigma," and an enigma cannot be forced into a binary comparison with another figure from the founding or reduced to one strain of thought. ${ }^{45}$

In light of the research completed on the values associated with the American Revolution in the last fifty years, it is time to examine how Wilson interpreted the constitutional controversy that emerged in the 1760's. This essay argues that Wilson's understanding of Anglo-American customary British constitutionalism ought to solidify his place at the pantheon of America's revered leaders during this critical time during the American Revolution and Constitutional periods.

\section{Mixed Government and Sovereignty: The Anglo-American Constitution}

\footnotetext{
${ }^{45}$ Smith, 393. Smith's description of Wilson as an enigma should not be taken to the extreme either. Wilson was an ambitious and intellectual man who might well be called an opportunist and or a pragmatist.
} 
In order to demonstrate Wilson's place in Anglo-American constitutional history, an effort must be made to define the tradition that he appealed to in the 1760's. In this case one could do worse than to quote legal historian John Phillip Reid who stated that "it will not do well to think of John Locke" in a discussion of the legal influences on the pre-revolutionary Whigs. ${ }^{46}$ Indeed the crisis was a constitutional one of two constitutions. The first was the constitution of the customary rights of Englishmen expounded by Sir Edward Coke against the encroachments of the royal prerogative by Charles I (1600-1649). The second, newer constitution, broke from that customary tradition that existed before the 1688 Glorious Revolution and embraced a doctrine of Parliamentary supremacy. The customary constitution and English law, especially the Common Law, was the "framework" for the American Whig argument. ${ }^{47}$ Colonials utilized Coke's resistance to the sovereignty of a branch of government during their constitutional crisis against the encroaching nature of the British Parliament. This indictment created "a constitutional tension" in during the age of the American Revolution. ${ }^{48}$ Coke's exchange with Charles I, the 1688 Glorious Revolution in England and America, and the English Bill of Rights (1689) place Wilson's 1768 pamphlet “Considerations on the Nature and Extent of the Legislative Authority of the British Parliament" in the appropriate context that he referenced: the customary constitution of mixed government.

Sir Edward Coke, Sovereignty \& the Case of the Five Knights

While the British colonists in North America struggled to adapt to the environment of the New World, Englishmen in the mother country began questioning King Charles I's claim of divine right. The Case of the Five Knights (1627) displayed the doctrine of divine right in its

\footnotetext{
46 John Phillip Reid, "In Our Contracted Sphere": The Constitutional Contract, The Stamp Act Crisis, and the Coming of the American Revolution," Columbia Law Review 76 (1976): 22.

${ }^{47}$ Bailyn, Ideological Origins, 31.

${ }^{48}$ Reid, In Defiance of the Law, 37.
} 
full: for "reasons of state" the King and his men argued, Charles I held the authority to deny habeas corpus. ${ }^{49}$ This royal argument made many uncomfortable in Parliament as for all practical purposes, Charles had declared martial law without consent from the representative assembly. In response to this act and under the leadership of Coke, the Parliament drafted a document entitled The Petition of Right (1628). The Petition marked a major affirmation of the traditional liberties of Englishmen against the encroaching power of an unlimited monarch. Called "the most valuable document to limit royal power since the Magna Carta," the Petition rattled off the rights of Englishmen as the House of Commons and Lords understood those rights historically. ${ }^{50}$ Among these affirmed liberties were habeas corpus, due process of law, and numerous provisions that sustained the role of Parliament in providing consent in the mixed constitutional order for matters of taxation and legislation. In the committee of the whole house, Coke read the petition aloud and stated "whereas by the common law and statutes every free man has a propriety in his goods and his estate, as no tax, tallage, etc., nor any soldier can be billete in his house ... by the King or any minister without an act of parliament." ${ }^{, 51}$ Just as important as the Petition itself was an amendment proposed during parliamentary debate that protected the sovereignty of the crown. Coke convinced the lower house to reject the language. ${ }^{52}$ When Charles learned of the bill and its contents, he demurred and it was not clear as to if he accepted the Petition as law. The monarch directed the Commons to reaffirm the Magna Carta. The Commons and the Lords confronted him, and read the Petition to him, and he agreed to it. This petition could be cited in the age of the American Revolution by both supporters of

\footnotetext{
${ }^{49}$ Catherine Drinker Bowen, "Sir Edward Coke" in The Spirit of American Law, ed. George S. Grossman (Boulder, CO: Westview Press, 2000), 46.

${ }^{50}$ George S. Grossman, ed., ibid., 43.

${ }^{51}$ Edward Coke, The Selected Writings of Sir Edward Coke: Volume III, Parliament (Indianapolis, IN: Liberty Fund, 2003), 1271.

52 Ibid., 1225.
} 
Parliamentary supremacy and the Anglo-American customary constitution; the former saw the

Petition as a means to increase Parliament's authority over the crown, while the latter saw it as a means to protect the liberties of Englishmen. Coke's contributions to English law extended also to the field of legal scholarship with the publication of his Institutes on the Law, where he combined legal statutes and charters with analysis. Coke's actions created more precedent for this mixed common law constitutional tradition; however, these efforts to affirm Parliamentary authority put Parliament and the King on a path to a brutal civil war. ${ }^{53}$ After the end of the English Civil War, Parliament restored the monarchy and Charles' son took the throne as Charles II. Charles II governed like his father before him and Parliament faced multiple skirmishes to retain its authority. This experience extended to the North American colonies, where the implementation of a royal plan to control the colonies threatened the existence of the colonial assemblies. Under Charles II and later during the reign of his brother James II, the crown ignited a systematic abolition of customary colonial assemblies and traditions. These events led to the Glorious Revolution of 1688 and shaped the English and colonial mindsets in a way that foreshadowed the response to royal power in the colonies in the late eighteenth century.

\section{The Colonial Experience \& The Glorious Revolution}

During the reign of James I and Charles I, the monarchs granted numerous land grants and charters to colonize America. The colonization of the New World was still in its infancy. ${ }^{54}$ The colonies organized themselves, and as Michael Kammen has pointed out, often formed

\footnotetext{
${ }^{53}$ Ellis Sandoz, The Roots of Liberty: Magna Carta, Ancient Constitution, and the AngloAmerican Tradition of Rule of Law (Indianapolis, IN: Liberty Fund, 1993), 3.

54 Three forms of colonization existed: joint-stock, proprietary, and royal colonies. All three forms received charters from the King of England. Colonies did not solidify until the midseventeenth century. The earliest surviving colonies date back to Jamestown in 1607, Plymouth in 1621, and Massachusetts Bay in 1630.
} 
colonial assemblies to govern their affairs. ${ }^{55}$ For example, individuals with interest in the jointstock colony of Virginia formed an assembly called the House of Burgess as early as 1619 to raise funds in the community for a small militia to ward off Native Americans and for the construction of roads and bridges. ${ }^{56}$ Five years later the colony was reorganized as a crown colony under James I and established a royal governor and a governor's council to govern alongside the House of Burgess. As time passed in the North American British colonies, similar systems formed following the precedent set by the Virginia Colony. ${ }^{57}$ The colonists revered these colonial assemblies and attached themselves to the ideal of delegate - or actual representation in dealing with matters in their locality. Over the course of the next few decades, England turned inward to deal with troubles at home under the rule of Charles I and legal skirmishes over the royal prerogative and parliamentary authority, a fight that erupted into the English Civil War (1642-1651). Protestant Oliver Cromwell established a military dictatorship to oversee English affairs in 1651, but struggled to rule. His attempt to make the Protectorate a hereditary form of government failed and the British Parliament restored the throne to Charles II in 1660. Charles appointed his younger brother James as Duke of York to handle colonial affairs and James oversaw the direction of colonial governors. A colonial governor served at the Duke's request and under James' instructions allowed colonists to form representative colonial

\footnotetext{
${ }^{55}$ See Michael Kammen, Deputyes and Libertyes: The Origins of Representative Government in Colonial America (New York, NY: Knopf, 1969). Kammen provided a collection of colonial charters as well as governing documents that the colonies created during the early years of colonization. These assemblies passed resolutions, declared their own rights and liberties, all while pledging allegiance to the King and his governors.

56 "Individuals with interest" was defined as white men over the age of twenty-one who owned property.

${ }^{57}$ Ibid., 11-12.
} 
assemblies with upper and lower houses and policy-making ability for those bodies provided that the governor and James approved it. ${ }^{58}$

One of the clearest articulations of colonial duties and expectations resided in one of the first declarations in New York's General Assembly in 1683. The colonists in the lower house drafted and approved a Charter of Libertyes and Privileges, where the assembly claimed that only the General Assembly could approve taxes in the colony and that the body was "Supreme." 59 Following the established legislative process outlined in the Duke's instructions to royal Governor Thomas Dongan, the Charter was passed, Dongan signed it, the Duke approved it, and sent it to Charles II where the royal ministry contended over the proclamation's contents before adopting a more strict administration in $1686 .{ }^{60}$ Charles established the Dominion of New England and centralized control of the area under one governor and began snatching up charters from New York to Massachusetts Bay. He dismissed Parliament, which angered Englishmen at home. However, he died in February 1685 and the Duke of York ascended to the throne and appointed Edmund Andros, a loyal advisor, to govern New England in 1686. Andros irritated the colonists further by denying them the ability to pass laws for themselves and tensions between the royal government and colonists exacerbated. The polices adopted by Andros incensed the inhabitants of Boston, Massachusetts.

James' ascension was not without controversy - an illegitimate child of Charles II, the Protestant Duke James of Monmouth - contested his rule in 1685. After James and his

\footnotetext{
${ }^{58}$ Kammen, 155-158. The information for this section comes primarily from New York Colony, a royal colony, where Thomas Dongan served as James' colonial governor.

${ }^{59}$ Ibid., 157.

${ }^{60}$ David Lovejoy, The Glorious Revolution in America (New York, NY: Harper and Row, 1972), 116. The New York General Assembly not only passed the Charter, but gave Governor Dongan a fee of some kind, a gift that most likely made the governor more receptive to the assembly's declaration.
} 
supporters crushed the royal challenge, he suspended Parliament like his father and brother before him. He repeatedly distributed the Declaration of Indulgence (1687), a document that provided religious tolerations for Catholics and circumvented Parliament's fierce Protestantism. These acts smacked of monarchical tyranny. The ousted representatives sought a remedy to their problem, found a solution in James' Protestant relatives William and Mary of Orange, and invited them to the English throne. James and his supporters launched a propaganda war while William made his way towards London. James abdicated the throne in December of 1688 and in February of 1689 a parliamentary convention elevated William and Mary. ${ }^{61}$ When word arrived in Boston, on April 4, 1689, of James' abdication, the colonists turned on Andros. The city of Boston declared that all acts perpetrated by James and Andros were illegal and particular reprehension was reserved for the suspension of colonial assemblies which left the colonists without "liberty" and made them "slaves." ${ }^{62}$ A mob surrounded Andros at his home in Boston and arrested him; they restored their charter's government (though interestingly enough, not the charter itself), and sent the imprisoned Andros to England in $1690 .{ }^{63}$ Rebellion spread across the colonies. ${ }^{64}$ As calm eventually came over the colonies, the colonists reformed their colonial assemblies which became symbols of British constitutionalism in North America.

Parliament examined how it could protect itself from the encroaching nature of the monarchy. With the parliamentary experience under James in mind, Parliament passed The

\footnotetext{
${ }^{61}$ This example demonstrates the delay in communication of the Glorious Revolution owed to the geographical gap between the colonies and England.

${ }^{62}$ Anon., "The Declaration of the Gentlemen, Merchants, and Inhabitants of Boston and the county adjacent," The American Republic: Primary Sources, ed. Bruce Frohnen (Indianapolis, IN: Liberty Fund, 2002), 101-105.

${ }^{63}$ Mary Lou Lustig, The Imperial Executive in America: Sir Edmund Andros, 1637-1714 (Madison, NJ: Fairleigh Dickinson, 2002), 216-22.

${ }^{64}$ One of the more significant rebellions that led to the establishment of a quasi-military dictatorship was Leisler's Rebellion in New York. See Jerome R. Reich, Leisler's Rebellion (Chicago, IL: University of Chicago Press, 1953).
} 
Declaration of Right. "Whereas the Lords Spirituall and Temporall and Comons assembled," began the Declaration, "lawfully and freely representing all the Estates of the People of this Realme." ${ }^{, 5}$ Parliament passed, and William consented to, an act that enshrined the contents of the Declaration of Right in law. The 1689 Bill of Rights declined the monarch powers to suspend or dispense laws, raise taxes, or form a standing army without the consent of the Parliament. ${ }^{66}$ It symbolized the triumph of the liberties of Englishmen over the royal prerogative, a fight that started with the Magna Carta and that past parliaments had waged.

The 1689 English Bill of Rights marked a stark departure for Parliament and English history for another reason, though at the time the Lords and Commons did not know it. Parliament had protected Englishmen from the encroachment of the royal prerogative, claimed supremacy for itself, and as a result founded a new constitution of parliamentary command. This supremacy fully revealed itself over the course of the next century after the 1688 Revolution and received its clearest articulation with regard to colonial affairs when the 1766 British Parliament asserted that it contained the power to legislate for the colonies in all cases whatsoever. The Americans could not understand how the same institution that fought against tyranny in the monarchy could embrace tyranny in the assembly. The events of the Glorious Revolution served as the basis for a new constitution of parliamentary supremacy over the Crown and over all of England. The ascension of William and Mary to the English throne and the concurrent rise of the constitution of parliamentary supremacy, in theory and in practice, faced questions at home and in the British North American colonies in the 1760's and 1770's. Most American did not dispute the fact that Parliament was sovereign, but they argued over whether or not this

\footnotetext{
${ }^{65}$ For a full copy of the Declaration, see Appendix 1 in Lois G. Schwoerer, The Declaration of Rights, 1689 (Baltimore, MD: John Hopkins University Press, 1981), 295-298.

${ }^{66}$ Ibid.; Wood, "The Origin of the Bill of Rights," American Antiquarian Society 101 (1991): 261.
} 
newfound sovereignty was limitless in both legality and constitutionality. To this point, John Phillip Reid has written, "the prerevolutionary Parliament was ... supreme and beyond legal restraint, but not yet so supreme that everyone thought it and the constitution were one." This experience remained fresh in the colonial imagination, as John Phillip Reid pointed out that the similarities between the treatment by James II in the 1680's and Parliament in the 1760 's were "obvious" to many. ${ }^{68}$ Though some in the eighteenth century accepted the doctrine of parliamentary supremacy, Englishmen in America, "whether whigs or tories" rejected that principle as "arbitrary government." ${ }^{\text {"69 }}$ Colonists who visited England during the 1688 such as Massachusetts Puritan Increase Mather believed that the parliamentary privileges established by the Declaration of Rights extended to the colonies. ${ }^{70}$ The Glorious Revolution, complete with its declarations and elevation of a monarch, further created evidence that affirmed consent in government was integral to British constitutionalism and hearkened back to Coke's enduring influence in law. ${ }^{71}$ In the colonies parliamentary sovereignty became force and command, due to the lack of influence the colonists had in the electoral process. ${ }^{72}$

\section{James Wilson: Mixed Government and the Anglo-American Constitution}

Fifty-four years later, in 1742, Alison Lansdale and William Wilson welcomed James Wilson into the world in their section of Scotland's Shire of Fife, a place known for its

\footnotetext{
${ }^{67}$ Reid, In Defiance of the Law, 42. For more on this sentiment in both England and America, see Chapter 5. Reid cited the example of Lord Camden who questioned the Parliament's authority to legislate taxes the midst of the Stamp Act Crisis.

${ }^{68}$ Reid, The Authority of Law, 54.

${ }^{69}$ Ibid., 55.

${ }^{70}$ Ian Steele, "Communicating an English Revolution to the Colonies, 1688-1689," Journal of British Studies 24, no. 3 (1985): 346.

${ }^{71}$ John Phillip Reid, The Concept of Representation in the Age of the American Revolution, University of Chicago Press, 1989), 18-19; Reid, The Authority of Law, 59.

72 "Yet in the development of the idea of sovereignty its representational basis was always in danger of being forgotten and falling away, leaving the sovereign authority simply as the stark power to command." Wood, Creation of the American Republic, 348.
} 
"individualistic, eccentric, and self-sufficient" citizenry and its "tradition of insubordination to civil authority." 73 Together, they raised young Wilson to appreciate the Bible and the Presbyterian religion, while they encouraged him to accept the call to become a minister. Wilson refused this call after spending a couple of years at the University of St. Andrews, where he grew intellectually and encountered the luminaries of the Scottish Enlightenment. Wilson absorbed the ideas of the likes of David Hume and Adam Smith, but gravitated more towards the school of the Scottish Enlightenment represented by Francis Hutcheson and Thomas Reid. ${ }^{74}$ Like Hutcheson, Wilson believed in a philosophy that encouraged education as a means of attaining the knowledge of higher truths. This pursuit led him away from his native Scotland, and he departed for the North American British Colonies, arriving in New York Harbor in 1765. After a short time in New York, Wilson headed for a city that earned the name "The Cradle of Liberty" for its place in Revolutionary and Constitutional history: Philadelphia, Pennsylvania. There, he attempted work as a tutor at the College of Philadelphia before abandoning that profession to read law under John Dickenson.

Wilson utilized the rhetoric of the Anglo-American customary constitution of the colonial experience throughout the 1760 's, but his most comprehensive grasp of the constitutionalism in which he lived appeared in his pamphlet, "Considerations on the Nature and Extent of the Legislative Authority of the British Parliament." According to Bernard Bailyn, the first wave of revolutionary pamphlets focused primarily on discussions of the historical differences between the Colonies and England, and sought to convince their opponents of the correctness of their rejection of the constitution of parliamentary supremacy. ${ }^{75}$ Wilson's pamphlet was published

\footnotetext{
${ }^{73}$ Smith, 3.

${ }^{74}$ See Hall, The Political and Legal Philosophy of James Wilson, 35-68.

${ }^{75}$ Bailyn, Ideological Origins, 17-18, 21.
} 
during this first wave of pamphlets and the lawyer in him sought to persuade colonists and Britons of his view. He postponed the publication of this pamphlet until 1774, when the revolutionary crisis was well underway. In it, Wilson reacted against the British Parliamentary assumption that the authority to legislate for the colonies rested in England, and not in the colonies. Wilson denied the position of William Blackstone that ultimate sovereignty rested in the British Parliament and became one of the first to deny parliamentary authority to legislate for both internal and external affairs. ${ }^{76}$ The pamphlet's argument contained three major themes: 1) the rights of Englishmen under the British constitution; 2) the nature of mankind and the institutional mechanism of elections; and, 3) the relationship between British Parliament and Ireland.

Wilson wrote in the first lines of the pamphlet that he based his denial of parliamentary authority on "the principles of justice and freedom, and of the British constitution." "77 However, the constitution that he claimed was the customary tradition that the Anglo-Americans understood as their historical relationship to the British Parliament and the Crown. Wilson appealed not to the doctrine of social contract or natural rights that emanated from a state of nature, but to the natural birth right of Englishmen in the British Empire, whether they resided in London or Boston. "Can the Americans," Wilson asked, "who are descended from British ancestors, and inherit all their rights be blamed - can they be blamed by their brethren in Britain - for claiming to still enjoy those rights?" age earlier in a 1764 pamphlet directed to the concerned public: "Was the blood of your ancestors polluted by a change of soil? Were they freemen in England and did they become

\footnotetext{
${ }^{76}$ Hall, ed., Works, 3.

${ }^{77}$ Wilson, Works, 3-4.

${ }^{78}$ Ibid., 3-4.
} 
slaves by a six-week voyage to America?"79 Wilson asked a follow up question to those who claimed that British liberties did not extend to the Americans: "Is not our honor and virtue as pure, our liberty as valuable, our property as dear, our lives as precious here as in England?",80 To Wilson, as to most Whigs, the idea of parliamentary sovereignty or supremacy was foreign to the Anglo-American customary constitution. The same constitution established that the happiness of a society was the first law of every government and off of this assumption Wilson posed the following question: "Will it ensure and increase the happiness of the American colonies, that the parliament of Great Britain should possess a supreme, irresistible, uncontrolled authority over them?",81 Surely, he answered, it was not the case. A change in the "imperial arrangement" by the king, the royal ministry, and Parliament was equivalent to "a breach of contract." 82

It is important to dwell for a moment on the use of the word "happiness." There is much debate over the use of this term by the leaders of the American Revolutionaries. It could be, as historian Jack P. Greene has written, that unity and public virtue played a role in the lateseventeenth century understanding of the term. ${ }^{83}$ Happiness to the American Whig, and more broadly to the eighteenth century mind, most often meant the acquisition of real property, or

\footnotetext{
${ }^{79}$ Anon., "A Letter to the People of Pennsylvania," ed. Bailyn, Pamphlets of the American Revolution: Vol. 1, 1750-1765 (Cambridge, MA: Belknap Press of Harvard University Press, 1965), 271.

${ }^{80}$ Wilson, Works, 14.

${ }^{81}$ Ibid., 3.

${ }^{82}$ Reid, "In Our Contracted Sphere," 30. Reid described the constitution of customary tradition well in calling it "home rule."

${ }^{83}$ Jack P. Greene, "Values and Society in Revolutionary America," Annals of the American Academy of Political \& Social Science 426 (1976): 53-69.
} 
land. ${ }^{84}$ Wilson discussed at length the link between property and society, or civilization, in his later law lectures. ${ }^{85}$

The next major argument that Wilson delivered was directed at the idea of representation and the institutional protections that elections provided for liberty.

What an instructive example is this! How alarming to those, who have no influence over their legislators-who have no security but that the power, which was originally derived from the people, wand was delegated for their preservation, may be abused for their destruction! Kings are not the only tyrants: the conduct of the long parliament will justify me in adding, that kings are not the severest tyrants! $!^{86}$

Indeed, Wilson believed that men fell from grace and that "[m]ankind are usually more affected with a near though inferior interest." ${ }^{, 87}$ Wilson thought that Parliament had forgotten its own mixed constitutional order: that the outcome of the Glorious Revolution was not a supreme Parliament, liberated from all restraint, but a Parliament that checked the King, a King that checked the Parliament, and a House of Lords that checked the House of Commons, and a Commons that checked the Lords. Thomas Jefferson echoed this perspective in his 1774 Summary View of the Rights of British America, when he wrote that "history has informed us that bodies of men, as well as individuals, are susceptible of the spirit of tyranny." 88 Wilson analyzed

${ }^{84}$ This amount of property one owned corresponded to the status of an individual in the social hierarchy in colonial America. This cultural value continued well into in the nineteenth century and unfortunately in southern states included the amount of slaves one owned as a marker of status. See Edward Pessen, "How Different From Each Other Were the Antebellum North and South?” The American Historical Review 85 (1980): 119-1149.

${ }^{85}$ Wilson, Works, 387-397. Wilson wrote that private property was superior to "common property." He also believed that it was a sound foundation for society and that history demonstrated that an attachment to private property "has, in some parts of the globe, covered barren heaths and inhospitable mountains with fair cities and populous villages."

${ }^{86}$ Works, 5, 10.

${ }^{87}$ Ibid., 17; Hall, The Political Philosophy of James Wilson, 72-73, 80.

${ }^{88}$ Jefferson, "Summary View of the Rights of British America: Set Forth in Some Resolutions Intended for the Inspection of the Present Delegates of the People of Virginia, Now in Convention, 1774" in The Papers of Thomas Jefferson, Vol. 1, 124. 
how the political order according to a supreme and sovereign Parliament removed a critical institutional mechanism from the hands of the colonists: frequent elections.

Elections formed the linchpin of the contract that the people of Britain created with Parliament and that the colonists created with their assemblies. Wilson cited legal treatise writer William Blackstone, who wrote that the British constitution "supposes that parliaments may betray [the people's] trust, and provides, as far as human wisdom can provide, that they may not be able to do so without long." $" 89$ Due to elections, the people of Britain demonstrated their approval or disapproval of particular policies; the same was true of the colonists and their relationship to their colonial assemblies. Through this process, "[ $\mathrm{t}]$ he constitution is frequently renewed, and drawn back, as it were, to its first principles; which the most effectual method of perpetuating the liberties of a state." 90 It was through this process that the people provided their consent: "no one has a right to any authority over another without his consent. All lawful government is founded on the consent of those who are subject to it." ${ }^{\text {91 }}$ If Parliament revoked colonial charters, abolished colonial assemblies, and legislated for the colonies from Great Britain, then "the temple of British liberty, like a structure of ice, would instantly dissolve."92 American Whigs tied ideas about consent, representation, and liberty together. Comparatively, British Tories disagreed with these ideas and presented their alternative doctrine of virtual

\footnotetext{
${ }^{89}$ Wilson, Works, 4. Ironically, Wilson disagreed with Blackstone on the location of sovereignty in the Empire. It was an eighteenth century belief that sovereignty must reside somewhere in government. Blackstone said the British Parliament; Wilson, the British people. See Wood, Creation of the American Republic, 350.

${ }^{90}$ Wilson, Works, 6. See also 723: "Parliaments were first annual; they were afterwards triennial; now they are septennial. This last period is surely too long. The members will be apt to forget the source from which they have received their powers."

${ }^{91}$ Ibid., 4.

92 Ibid., 5.
} 
representation. ${ }^{93}$ To the Tories, the Whig idea of consent meant that no law applied unless an individual personally voted in favor of it. ${ }^{94}$ Such an idea inevitably led to anarchy. The American Whigs postponed answering these questions about representation in full until Constitutional Convention of 1787.

The example of Ireland's experience with Parliamentary legislation provided further ammunition for Wilson's pamphlet. “[T]he people of Ireland were not bound by an act of parliament made in England," Wilson argued, "The Irish did not send members to parliament; and, therefore, they were not bound by its acts." 95 According to John Phillip Reid, the colonial imagination noticed the Irish example after the passage of the 1765 Stamp Act and the 1767 arrival of British troops in Boston harbor. ${ }^{96}$ Indeed, the idea that the colonists were not only the subject of the King, but of the Parliament gave rise to the idea that the colonists were subjects of subjects. ${ }^{97}$ Such an idea was incredulous to the colonists' ideas about liberty and with a rhetorical flourish they asked - how could one subject be another's superior when they were equal in England?

Wilson's pamphlet denied the doctrine of parliament sovereignty over the colonies in full force. The implications of his pamphlet included the idea that original sovereignty belonged to the people themselves. A year later, in 1775, Wilson delivered a speech at convention in Philadelphia, Pennsylvania. He argued that the colonists had exercised patience in the lingering disagreement regarding sovereignty. He asked, "Were we rash or seditious? Did we betray want

\footnotetext{
${ }^{93}$ Bruce Frohnen, "Revolutions, Not Made, but Prevented," in Vital Remnants, ed. Gary L. Gregg (Wilmington, DE: Intercollegiate Studies Institute Books, 1999), 294-295.

${ }^{94}$ Wood, Representation in the American Revolution (Charlottesville, VA: University of Virginia Press, 2008), 17.

${ }^{95}$ Wilson, Works, 19.

${ }^{96}$ See Reid, In Defiance of the Law at Chapter 7.

${ }^{97}$ Reid, The Authority of Law, 80.
} 
of affection to our brethren in Britain?" ${ }^{98}$ After the 1766 repeal of the Stamp Act, the colonists were "lulled into delightful security," but such security proved to be temporary, as Parliament "pursued their scheme of depriving [the colonists] of their property . . . and to degrade [them] to a rank inferior [sic] to that of freedmen." 99 Wilson walked his audience through the events of the past few years: the boycott against British goods, the 1766 declaratory act, and the 1773 tea tax. It infuriated the lawyer in Wilson that in Boston, men were rounded up without a court of their peers. If these acts were allowed in Massachusetts, what prevented them from occurring in Pennsylvania? The full blown conspiracy was revealed: "the colonists, it seems, must be stript [sic] of their judicial, as well as of their legislative powers. . . Their constitutions must be changed: their liberties must be abridged.",100

Though Reid has asserted that it must have confused, even angered, the adherents of Parliamentary supremacy that the colonists referred to an unwritten constitution, Wilson addressed those concerns through his legal acumen and erudition. ${ }^{101}$ He embraced the British customary constitution and threw the constitution of parliamentary supremacy into the air. Wilson looked back through English history and asked if the 1215 signing of the Magna Carta at Runnymede, the 1660 Restoration, the 1688 Glorious Revolution, were "authorized by the constitution."102 Wilson went even further and claimed the mantle of those "venerable assemblies" and British liberty for the colonists. ${ }^{103}$ These acts and crimes amounted to a fullfledged attack on the entirety of the North American British colonies, so Wilson argued. The

\footnotetext{
${ }^{98}$ Wilson, Works, 33.

99 Ibid.

${ }^{100}$ Ibid., 35.

${ }^{101}$ Reid, "In Our Contracted Sphere," 33.

${ }^{102}$ Wilson, Works, 37.

${ }^{103}$ Ibid.
} 
outcome of these acts forced the colonists to discuss how to best move forward in light of the crisis of liberty in a convention.

By this means, a chain - more inestimable, and, while the necessity for it continues, we hope, more indissoluble than one of gold - a chain of freedom has been formed, of which every individual in these colonies, who is willing to preserve the greatest of all human blessings, his liberty, has the pleasure of beholding himself a link. ${ }^{104}$

However, even with the meeting of the Continental Congress, Wilson held out hope that this crisis was temporary and that nowhere had colonials given separation from Great Britain a serious thought. He proceeded to read a proposal to the assembly that condemned the 1774 acts of Parliament and George III to punish Boston for the December 1773 Boston Tea Party as well as stated that it was the duty of British citizens to resist those unreasonable actions.

Reaffirming his findings in "Considerations," Wilson found no authority for Parliament to alter colonial constitutions and declared, "We do not send members to the British Parliament; we have parliaments of our own."105 This argument roiled royalists as it asserted that the colonial assemblies were co-equal with the British Parliament. Unlike other countries, Wilson stated that "an original contract" between the British people and government was formed by the Glorious Revolution and that event enacted principles of limited government against the King and that no such right ever existed in Parliament's purview. ${ }^{106}$ In summation, Wilson called the arguments against the colonists "an enchanted castle," that "never had any real existence," once the "genuine rays of liberty and of the constitution dart[ed] in.".107

${ }^{104}$ Ibid., 36. This passage is critical to understanding Wilson's later thought on the nature of the Union of the colonies as they left the British Empire - they did so united. This aspect of his political thought will be discussed in the next chapter.

105 Ibid., 39.

106 Ibid., 40-41.

${ }^{107}$ Ibid., 43. 
The last document Wilson authored during the Revolutionary era he co-authored in 1776 at the Continental Congress with other delegates, including his legal mentor John Dickenson, William Hooper, James Duane and Robert Alexander. ${ }^{108}$ In February, months before the publication of Jefferson's Declaration of Independence, this group wrote that "all Power was originally in the People," and that this power included that delegated to Parliament and the King. ${ }^{109}$ It stated that the colonial assemblies were co-equal with the House of Commons and that the latter body could not have "any Power deriv'd from the Inhabitants of these Colonies." "110 The address reiterated similar arguments that Wilson made in his speech in Pennsylvania - at some points using the exact same language. The men pledged their allegiance to the British government, but held something marginally higher than their allegiance to England: Liberty. They thundered, "We are desirous to continue Subjects: But we are determined to continue Freemen. .. . That the Colonies may continue connected, as they have been, with Britain, is our second Wish: Our first is - that America may be free."111

\section{Wilson's Constitutional Era}

Within the first decades of independence, a group of revolutionaries realized that the Continental Congress and the Articles of Confederation could not provide an effective governing structure. The general sense of the Confederation was that it was structurally weak in dealing with the issues of the critical period. ${ }^{112}$ The loose Confederation government placed enormous

\footnotetext{
${ }^{108}$ Hall, ed., Works, 59. A note from Worthington C. Ford, editor of the Journals of the Continental Congress stated that the manuscript of the address is in Wilson's handwriting. Additionally, Madison's copy contained a note where he wrote that Wilson claimed the purpose of the address was to lead the public to independence.

${ }^{109}$ Wilson, Works, 46-47.

${ }^{110}$ Ibid.

111 Ibid., 58.

112 John Randolph of Virginia recited a litany of the defects of the Articles of Confederation government in his remarks on May 29. Chief among the defects were a lack constitutional
} 
power in the hands of legislative assemblies, as the place where Americans had historically governed themselves. According to Gordon Wood, Madison and others believed that state assemblies were incompetent in the ability to execute the laws they passed. ${ }^{113}$ An anonymous editorial in the Daily Advertiser of New York ran, "The necessity of the Convention has been generally admitted and almost universally felt." ${ }^{\prime 14}$ The first essay in the Federalist stated that "nothing less than the existence of the UNION" was at stake. ${ }^{115}$ It was in this environment that the Continental Congress directed states to form a revision of the Articles of Confederation. Wilson arrived to the Convention on May 14, 1787 with his ideas about representation from the colonial and revolutionary experiences and fellow Pennsylvania delegates Robert Morris, Thomas Fitz Simmons, and Gouverneur Morris. ${ }^{116}$ The notion that the true authority of government originated in the people and that the governed expressed their consent through elections found no better advocate than James Wilson at the Philadelphia Convention. Indeed Wilson proved himself one the most important influences on the Constitution and according to James Read Wilson was "second only to Madison." "117 He had achieved prominence during the Revolution through his association with Dickenson and limited interaction with Benjamin

power for the Continental Congress to provide security among the states, to suppress rebellions, and protect national legislature from state power. See Max Ferrand, ed., The Records of the Federal Convention of 1787 (New Haven, CT: Yale University Press, 1966), 19; Wood, Creation of the American Republic, 393-429.

${ }^{113}$ Wood, The Creation of the American Republic, 306.

${ }^{114}$ Anon., "A Revolution Effected by Good Sense and Deliberation," Debates on the Constitution, Bailyn, ed., (New York, NY: Literary Classics of the United States, Inc., 1993), 12.

${ }^{115}$ Hamilton, "Federalist No. 1," eds. George Carey \& James McClellan, The Federalist (Indianapolis, IN: Liberty Fund, 2001).

${ }_{116}^{116}$ Records (I): 1.

${ }^{117}$ Read, Power Versus Liberty, 92. 
Franklin, but he further increased his profile through his service in the Continental Congress and the publication of a 1785 essay titled "Considerations on the Bank of North America." 118

In his second "Considerations," Wilson argued that Congress held the implied power to charter a national bank and denied the authority of his fellow Pennsylvanians to interfere in the execution of its actions. His concept of implied powers extended to "general rights, general powers, and general obligations" that "resulted from the union" of all of the states under the Articles of Confederation. ${ }^{119}$ This union contained all the powers that the laws of nations were implicit in the nature of national governments. As Bradley Caffee has noted, an increase of implied powers under the Articles of Confederation never occurred, the majority of representatives believing the Articles did not allow for a strong central government and that a policy of implied powers could "quickly slip into arbitrary power and a new parliamentary tyranny."120 This crisis demanded more than legislation passed by the Congress; the Congress needed a stronger foundation of authority and a mechanism to carry out Congressional orders. In September 1786, concerned state delegates made an effort to meet in Annapolis to discuss a revision of the Articles but seeing as only five states attended the Annapolis Convention, the group moved to discuss more general revisions to the Articles in Philadelphia the following year, 1787. When Wilson arrived at the Philadelphia Convention, his position on the limits on the power of government was clear. Wilson's ideas about the proposed federal government and his opposition to a federal bill of rights found a home with the "court-party nationalists" and became "the basis of all Federalist thinking" through his debates at Convention and his position on the

\footnotetext{
${ }^{118}$ Wilson, Works, 60-79; Caffee, "Progressive Constitutionalist," 81-84.

${ }^{119}$ Wilson, Works, 66. For a synthesis of breakdown of other major convention delegates and their respective understandings of the implied or necessary powers of government, see Forrest McDonald, Novus Ordo Seclorum: The Intellectual Origins of the Constitution (Lawrence, KS: University Press of Kansas, 1985), 267-268.

${ }^{120}$ Caffee, 85.
} 
Committee of Revision for the final document. ${ }^{121}$ The question remained: on what authority would this new foundation rest?

\section{The True Locus of Sovereignty}

The location and nature of sovereignty in the colonies was a discussion that the Whigs postponed during the Revolution, at least in the formal, constitutional sense. ${ }^{122}$ As distinguished historian Forrest McDonald has written, the Declaration of Independence was "ambiguous" about sovereignty and the thinkers of the eighteenth century understood the term as "the absolute power to command anything and everything that was naturally possible." ${ }^{\prime 23}$ Prominent lawyers and other learned men obsessed over the location of sovereignty as "the most important theoretical question" before the 1787 Convention. ${ }^{124}$ As Wilson demonstrated in convention, he formulated the most comprehensive answer to the question. He thought that the neither the Declaration nor history was ambiguous in this matter: the people were sovereign. ${ }^{125}$ As a result of this thinking he gravitated to the idea of popular elections, easily one of the most recognizable features of the Anglo-American customary constitution.

${ }^{121}$ McDonald uses the term "court-party nationalists" to describe the more elite men at the Convention who admired the British government and were concerned about the honor of the United States. This admiration of the British system centered upon the mixed constitutional order created by a partially republican government. See McDonald, Novus Ordo Seclorum, 186-189 \& Wood, Creation of the American Republic, 202-206, 530; Bailyn, Ideological Origins, 328.

${ }^{122}$ Read, Power Versus Liberty, 92.

${ }_{123}^{123}$ McDonald, Novus Ordo Seclorum,150, 278-279.

${ }_{125}^{124}$ Wood, Creation of the American Republic, 354.

${ }^{125}$ The modern mind will recognize that Wilson's support of popular elections contained a caveat. As he explained in his law lectures, he favored an extension of suffrage "as far as considerations of safety and order" allowed. He truly believed that, as he said, "the correct theory and true principles of liberty require, that every citizen, whose circumstances do not render him necessarily dependent on the will of another, should possess a vote in electing those, by whose conduct his property, his reputation, his liberty, and his life, may be all most materially affected." In his context, Wilson's position was culturally accepted. He also admired the Constitution for allowing the states to determine their own qualifications for their electors. Wilson, Works, 838. 
Wilson argued for the formation of a popularly elected bicameral legislature and a large one at that. ${ }^{126}$ Most of the delegates at the Convention agreed in the propriety of an immediate election for the lower house of the national legislature; however, some delegates hesitated to embrace the idea of immediate elections for the upper house. "The people," said Roger Sherman of Connecticut, "should have as little to do as may be about the Government."127 Elbridge Gerry of Massachusetts attributed most "evils" under the Articles to an "excess of democracy.",128 Wilson thought that the new "federal pyramid" he envisioned required the "broadest base possible" of direct support from the people and that the independence of the upper house depended upon the same principles of a wide base of input from the voters in this "pyramid of government." ${ }^{129}$ He espoused proportional representation based on population not only for the House, but also for the Senate. His fundamental belief being that sovereignty resided in the people and the colonial experience at hand, he proposed that the Convention ought to establish national districts for the election of Senators. Wilson was not clear about the structure of these hypothetical federal districts, but it seemed he intended for voters among several states, or sections of several states, to vote for a Senator. This method of election structured a reliance on the people, yet it provided a different constituency than the voters in the local districts for House of Representatives. This proposal did not obtain much support among the other delegates for representation in Congress. Indeed, no other delegate commented on Wilson's idea save for Madison who anticipated that the proposal only served to further exacerbate the perception that

\footnotetext{
${ }^{126}$ Records (I): 252-253. Wilson believed that a large body was necessary as he noted that "the smallest bodies in Great Britain are notoriously the most corrupt."

${ }^{127}$ Records (I): 48.

128 Ibid.

${ }^{129}$ Records (I): 57. For Wilson's frequent use of the pyramid metaphor, see Ralph Rossum, 'James Wilson and the 'Pyramid of Government:' The Federal Republic," Political Science Reviewer 6 (1976): 113-134.
} 
the Convention sought to diminish the power of smaller states. ${ }^{130}$ When Charles Pinckney of South Carolina moved later in the Convention to again grant the mode of election to the state legislatures, Wilson continued in his disposition that the "vigorous authority to flow immediately from the legitimate source of all authority."131 Though Wilson lost the battle for proportional popularly elected representation in the Senate with the June 5 draft of the Constitution created by a select committee, he continued to offer his arguments for popular elections in other aspects of the new government as he did for the Presidency.

Wilson argued that precedent already existed for the popular election of single executives. He looked to the popularly elected governors in New York and Massachusetts as cases that proved the immediate election of a single executive by the people was the ideal method of selection for the executive as "the best safeguard against tyranny."132 "Extend the sphere," Madison wrote about congressional elections in the extended republic in November 1787, "and you take in a greater variety of parties and interests." ${ }^{133}$ Wilson's defense of a popularly elected presidency was rooted in the same principle, but where Madison argued for this principle in the legislative branch Wilson supported its incorporation into the executive branch as well. In time, the Convention agreed to a modification of Wilson's federal district proposal as a blueprint for the Electoral College. Sherman disagreed with Wilson's pleas for a single executive, citing that most of the state legislatures established governor's councils to represent the people in the governor's office. ${ }^{134}$ Wilson did not believe such a council necessary

\footnotetext{
${ }^{130}$ Records (I), 52-58.

${ }^{131}$ Ibid., 132-133. Wilson went on to say, "the government ought to possess no only $1^{\mathrm{ST}}$ the force, but $2^{\mathrm{NDLY}}$ the mind or sense of the people at large. The Legislature ought to be the most exact transcript of the whole society."

132 Ibid., 65-66.

133 James Madison, "Federalist No. 10," in The Federalist, 48.

${ }^{134}$ Ibid., 97.
} 
and articulated a theory of checks and balances that insisted on the single executive's reliance upon a national popular election every three years before he condemned the folly that of a plural executive. He cited the leadership experience of Rome with Julius Caesar and Augustus in the triumvirates to demonstrate the tendency of one in a plural executive to "become the master of his colleagues." "135 “Among three equal members," Wilson argued that governance would sink to “[uncontrolled], continued, \& violent animosities; which would . . . diffuse their poison thro' the other branches of Govt, thro' the States, and at length thro' the people at large."136 A young Alexander Hamilton found common ground with Wilson on this point in the Convention and later echoed the sentiment in Federalist 70 when he wrote for the need of "energy" as being critical to the preservation of political liberty. ${ }^{137}$

Wilson also argued that his popularly elected executive could protect the Union from tyranny only if the office came with the powers that allowed the executive to reject law that passed the legislature. Wilson agreed in the necessity of "an absolute negative" on law that came out of the legislative branch, but believed that the judiciary deserved revisionary power as well. ${ }^{138}$ Once more Sherman rose in opposition, as he thought it was wrong to allow "one man to obstruct the will of the whole."139 Wilson expected the use of an executive veto to be rare, as the sheer threat of rejection would prevent the Congress from passing legislation that the President disliked. An additional power that Wilson tried to grant the national government was a federal veto of state laws. Though he was successful in securing a presidential veto in the final version of the Constitution, he did not achieve a wider grant for the national government of state law, or

\footnotetext{
${ }^{135}$ Ibid., 254.

136 Ibid., 96.

137 Alexander Hamilton, "Federalist No. 70," in The Federalist, 363.

${ }^{138}$ Records, 98-100.

139 Ibid.
} 
revisionary power for the judiciary. ${ }^{140}$ These opinions in checking the power of the legislature placed Wilson in a position that his critics used to call him an aristocrat and anti-democratic. ${ }^{141}$

Wilson also engaged in the debate over the status and representation of African slaves under the new government established by the Constitution. The admission of slaves as threefifths of a person confused him and he "did not well see on what principle the admission blacks in the proportion of three fifths could be explained. Are they admitted as Citizens? then why are they not admitted as on an equality with White Citizens? are they admitted as property? then why is not other property admitted into the computation?" 142 It should be clear that he agreed to the three-fifths clause as matter of political expedience to keep the southern states at the Convention and did not in any way advocate for race equality. However, his comments shed light on how the delegates at the Convention struggled to make sense of the institution of slavery in the new government. It was curious, as Nathaniel Gorham of Massachusetts commented, that when discussing taxation the southern states argued that slaves were inferior to freedmen, but when discussing representation they were equal. ${ }^{143}$

\section{The Revolution, the Constitution, and National Identity}

In the midst of Wilson's comments at convention, another theme presented itself in his comments: an antagonism towards the states and their respective claims of sovereignty by the Anti-Federalists. Massachusetts delegate Rufus King articulated the Federalist sentiment well when he said, “The States were not 'sovereigns' in the sense contended for by some. They did

\footnotetext{
${ }^{140}$ The United States Supreme Court has developed a revisionary power over both the executive and legislative branches through the process of judicial review that allows the Court to uphold or deny the constitutionality of laws. There was general agreement during the Convention that this power would exist.

${ }^{141}$ Hall, Political Philosophy of James Wilson, 127-138.

142 Ibid., 587.

${ }^{143}$ Ibid., 580.
} 
not posses the peculiar features of sovereignty. They could not make war, nor peace, nor alliances, nor treaties. Considering them as political Beings, they were dumb, for they could not speak to any forign [sic] sovereign whatever." "144 To this position, some in Convention claimed that in declaring independence the states entered a state of nature. Wilson could not stomach the assertion and responded by reading the Declaration of Independence, noting that the phrase "United Colonies" was used. ${ }^{145}$ He feared that the proponents of state sovereignty wished to mire the proposed government in local interests, when they were actually "one nation of brethren."146 Unlike Hamilton, Wilson believed that the states and new national government could exist on kind terms with one another. ${ }^{147}$ Another facet of the sovereign people can be recognized in Wilson's defense of the special ratifying conventions that he and Madison championed. Madison believed that the ratification of the proposed Constitution by the people was "essential" and that any option that placed control of ratification in the hands of the states would lead to the idea that the states were sovereign entities. ${ }^{148}$ Such a doctrine might lead to the destruction of the Union with "a breach of any one article, by any of the parties."149 Wilson agreed, and floated the idea that a "partial union" of the states that ratified the Constitution would be open to the admission of the other states at a later time. ${ }^{150}$

Once Wilson left the Convention, he lobbied for the adoption of the Constitution in Pennsylvania's ratifying convention where he clashed with Anti-Federalists. No issue divided the Federalists and Anti-Federalists more than the debate surrounding the lack of a national bill

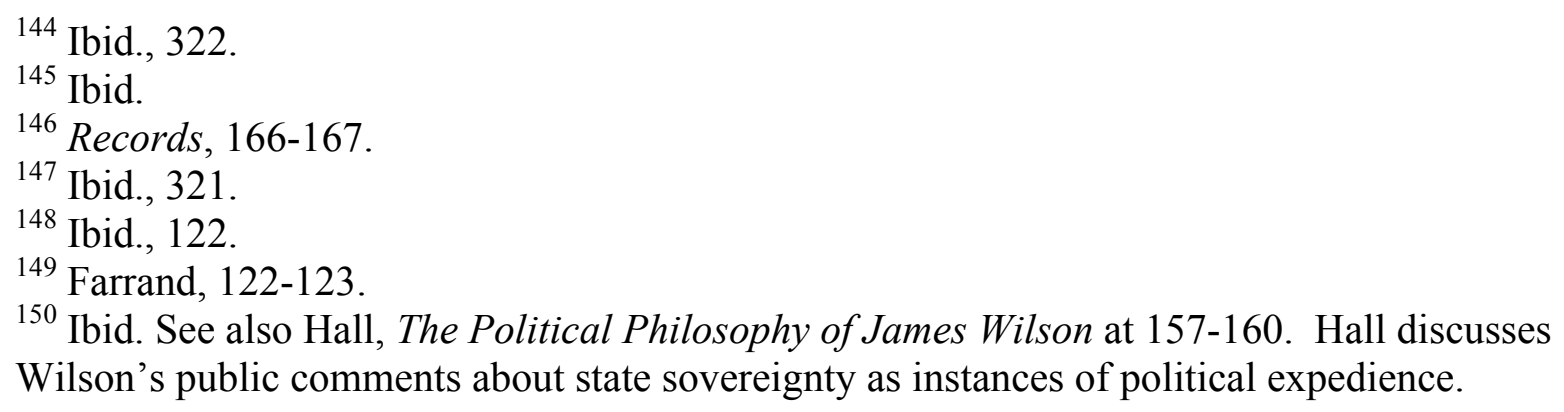


of rights in the new document. To this end, Wilson delivered one of the most impassioned Federalist speeches of the era in the Pennsylvania State Court House Yard on October 6, 1787, in which he dismantled the Anti-Federalist argument about the need for a federal bill of rights. ${ }^{151}$ Though Wilson held an expansive view of the implied powers of government, as demonstrated by his 1785 "Considerations" pamphlet regarding the implicit power of the Articles to charter a bank, he dismissed Anti-Federalists fears that "the different state constitutions are repealed and entirely done away" by the ratification of the Constitution. ${ }^{152}$ On the contrary, Wilson argued that the existence of the national government depended upon the existence of the states through the grant of power to them for the selection of Senators and electors to the Electoral College. ${ }^{153}$

Three explanations can be offered for what looked like a contradiction in Wilson's thinking. One of the justifications he presented in the Pennsylvania ratifying convention was that many of the other delegates present at the Philadelphia Convention simply did not think a bill of rights necessary. ${ }^{154}$ Secondly, he and other Federalists argued that including a bill of rights in the federal government served not to protect the people, but rather to take away power from them. "A bill of rights," Wilson remarked, "annexed to a constitution is an enumeration of the powers reserved." 155 Wilson and other leaders at the time had no way of knowing what would be included in a bill of rights and expressed that as contrary to the implicit grant of power to state governments under the Articles of Confederation, "the positive grant expressed in the instrument of Union" through the ratifying conventions allowed the people to reserve their

\footnotetext{
${ }^{151}$ Wilson, Works, 171-177.

${ }^{152}$ Anon., "Brutus, Essay II on Nov. 1, 1787," ed. Lance Banning, Liberty \& Order: The First American Party Struggle (Indianapolis, IN: Liberty Fund, 2004), 6-9.

${ }^{153}$ Wilson, Works, 174-175.

${ }^{154}$ Ibid., 194.

155 Ibid., 195.
} 
power. ${ }^{156}$ It doubled as a political argument that Federalists could utilize against the AntiFederalists. ${ }^{157}$ The claim of state sovereignty by Anti-Federalists assumed that the people were not the true foundation of authority and this odious argument stunned Federalists like Wilson. Thirdly, Wilson espoused an optimistic belief that the new government and frequent elections structured the people's affiliations in a way that kept the government in touch with the principles of the Anglo-American customary constitution. The defense provided by frequent elections - the choice to grant a leader office or not - offered more protection of political and civil liberty than the parchment barriers created by a bill of rights. In the Pennsylvania ratifying convention, he acknowledged the importance of the 1215 Magna Charta and the 1689 Declaration of Right, but the existence of these documents did not ensure the King or Parliament's adherence to the principles embodied by those documents. ${ }^{158}$ The Revolution was unnecessary if passing resolutions protected the principles of civil and political liberty. This third argument seems naïve, but the fact that within the two decades the people of the United States initiated the systematic obliteration of the Federalist Party over the 1798 Alien and Sedition Acts might serve as evidence to make Wilson's argument more credible in his context: that the people were capable of ridding themselves of illiberal leaders when they rose to power. ${ }^{159}$ To the twenty first century mind, Wilson's logic appears not only weak, but also difficult to understand. To him, in his historical context, however, the logic was clear.

Wilson took to comparing the 1787 Federal Constitution to Great Britain's in one of his lectures he delivered between 1791 and 1792 at the University of Pennsylvania. He harangued

\footnotetext{
${ }^{156}$ Ibid., 172.

${ }^{157}$ Hall, Political and Legal Philosophy, 161.

${ }^{158}$ Wilson, Works, 195-196.

${ }^{159}$ Many of the 1787 Convention delegates believed that future leaders ought to attend a national university to educate the next generation in the ways of republican virtue and dedicated to constitutional principles. See McDonald, Novus Ordo Seclorum, 190-191.
} 
against Parliament's claim of supremacy that ignited the Revolution. Wilson denied Great Britain the title of constitutional government with his statement that "no such thing as a constitution, properly so called, is known in Great Britain. What is known, in that kingdom, under that name, instead of being the controller and the guide, is the creature and the dependent of the legislative power."160 The Americans threw off this arbitrary feature of government that existed in the British system through the Revolution. Wilson roundly criticized Blackstone, who believed that the British Parliament could not be limited and every law it enacted was as constitutional. In the United States, under the Constitution, the legislature was ideally beholden to an institutional check upon its power: the judiciary. Beaming at the ingenuity of the system, Wilson exclaimed, "[an] effectual provision is made, that the transgression of [legislative] bounds shall be adjudged and rendered vain and fruitless. What a noble guard against legislative despotism!"’161

\section{Chisholm v. Georgia (1793)}

Wilson's contributions to Federalist thinking did not stop with his attendance at the Constitutional Convention or Pennsylvania’s ratifying convention. In 1789, President George Washington appointed and the Senate approved Wilson as an Associate Justice of the United States Supreme Court. Wilson again confronted the sovereign state argument in the case Chisholm v. Georgia (1793). With the Constitution enacted, he appealed to its text in order to rebut Georgia's claim that nonresident citizens lacked standing to sue states in which they did not live. The events of that case dated back to 1777, when South Carolinian merchant Robert Farquhar sold wartime supplies to Georgia representatives Thomas Stone and Edward Davies for revolutionary forces stationed in Savannah. Farquhar delivered the goods, but never received

\footnotetext{
${ }^{160}$ Wilson, Works, 718.

${ }^{161}$ Ibid., 743.
} 
payment even though he requested payment multiple times until 1784. In that year Farquhar suffered an unfortunate incident that led to his drowning at sea. Farquhar's will named Alexander Chisholm as an executor of the estate and, in 1777, Chisholm sued Georgia for the payment of goods that Farquhar delivered. Chisholm first filed in district court and the presiding justices in Georgia ruled that a citizen of South Carolina could not sue a state where the plaintiff did not reside. Chisholm appealed to the United States Supreme Court, seeking a remedy for his injury. In a political stunt, Georgia refused to appear before the Supreme Court after repeated invitations to argue their case that the jurisdiction of the United States Supreme Court did not extend to matters of state sovereignty. ${ }^{162}$

In a four to one opinion, the justices ruled that Georgia and all other states were subject to the authority of the Constitution, including the judicial oversight of Article III. Associate Justice Wilson systematically admonished Georgia. He framed the opinion of the Court in a question, "[D]o the people of the United States form a Nation?"163 Wilson knew that in the United States the origin of governmental authority stemmed from the citizens that lived under it and drew on the Scottish Enlightenment, Natural Law, the Anglo-American customary constitution, the Revolution, and the 1787 Constitution. Wilson bellowed, "To the Constitution of the United States, the term SOVEREIGN, is totally unknown. There is but one place where it could have been used with propriety. . . . [The Ratifiers] might have announced themselves 'SOVEREIGN' people of the United States." ${ }^{164}$ In the latter pages of the opinion, Wilson continued articulating his view that when the people of the United States enacted the Constitution, they enacted the entire document. The people, he insisted, meant to empower the legislature with legislative

162 Doyle Mathis, "Chisholm v. Georgia: Background and Settlement," The Journal of American History 53 (1967): 23-24.

${ }^{163}$ Wilson, Works, 351.

${ }^{164}$ Ibid., 352-353. 
power, the executive with executive power, and in this case, the judiciary with judicial review. "The people of the United States," Wilson wrote, "intended to form themselves into a nation for national purposes. ${ }^{\prime 165}$

By reading Wilson's thoughts on the nature of those who ratified the Constitution in the ratifying conventions in the late 1790 's, one can see glimmers of the nationalist sentiment he expressed at the Philadelphia Convention and even back to his thoughts on the Bank of North America. In Chisholm, Wilson concluded "that the citizens of Georgia, when they acted upon the large scale of the Union, as a part of the 'People of the United States,' did not surrender the Supreme or Sovereign Power to that State but, as to the purposes of the Union, retained it to themselves. As to the purposes of the Union, therefore Georgia, is NOT a sovereign state."166 With the forceful declaration from the bench, Wilson quieted the debate (at least for some time) on the issue of state sovereignty. It was the theory expanded by Jefferson and Madison with the 1798/99 Kentucky and Virginia Resolutions in response to Adam's Alien and Sedition Acts, intensified with the 1832 Nullification Crisis, and endorsed by John C. Calhoun in the 1830's to justify the rebellion of southern states in the Union over the issue of slavery. Though with the ratification of the Eleventh Amendment the states nulled the Chisholm opinion, Wilson, Chief Justice John Marshall, President Andrew Jackson, and President Abraham Lincoln stood against this argument of the sovereignty of the states and the so-called Compact Theory of the Union.

\section{Conclusion}

The political and legal thought of James Wilson is saturated with Natural Law influences, as demonstrated by a read of his law lectures, but the purpose of this essay was to argue the equal

${ }^{165}$ Works, 365. With those familiar with Chief Justice John Marshall's (1755-1835)

jurisprudence from 1801-1835, the Chisholm opinion sounds similar to the arguments he would later use.

${ }^{166}$ Ibid., 357 (emphasis is Wilson's own). 
importance of Wilson's Anglo-American customary constitutional arguments during the prerevolutionary, revolutionary, and constitutional eras. As the product of multiple intellectual influences, Wilson was a complex individual. He articulated a steadfast belief that the constitution was rooted in 1) the mixed constitutional order expressed by Coke and the 1688 Glorious Revolution, and 2) the British colonial experience in North America. American Whigs during the Revolution identified their colonial assemblies and elections as symbols of an inextricable constitutional tradition of representation and liberty. Wilson personified these ideas and he was one of the few Whigs who appealed to these traditions to disavow British Parliamentary authority in the colonies and then attempted to enshrine these political and constitutional concepts in the 1787 Federal Constitution. His efforts continued in his jurisprudence as an Associate Justice of the United States Supreme Court, and his ideas regarding the sovereignty of the people of the United States resonate today. Wilson dedicated his life to the preservation of liberty and constitutionalism in law; the importance of which he declared in his law lectures, "it is only under a good constitution that liberty - the precious gift of heaven - can be enjoyed and secured."

${ }^{167}$ Ibid., 715-716. 


\section{Bibliography}

\section{Primary Sources}

Bailyn, Bernard, ed. Debates on the Constitution. 2 Volumes. New York, NY: Literary Classics of the United States, Inc., 1993.

Pamphlets of the American Revolution. 4 Volumes. Cambridge, MA: Belknap Press of Harvard University Press, 1965.

Banning, Lance, ed. Liberty \& Order: The First American Party Struggle. Indianapolis, IN: Liberty Fund, 2004.

Coke, Sir Edward. The Selected Writings of Sir Edward Coke. 4 Volumes. Indianapolis, IN: Liberty Fund, 2003.

Ferrand, Max, ed. The Records of the Federal Convention of 1787. 4 Volumes. New Haven, CT: Yale University Press, 1966.

Fronhen, Bruce, ed. The American Republic: Primary Sources. Indianapolis, IN: Liberty Fund, 2002.

Hamilton, Alexander. The Papers of Alexander Hamilton. 24 Volumes. Harold Syrett \& Jacob Cooke, eds. New York, NY: Columbia University Press, 1961.

Hamilton, Alexander, John Jay \& James Madison. The Federalist. George Carey \& James McClellan, eds. Indianapolis, IN: Liberty Fund, 2001.

Jefferson, Thomas. The Papers of Thomas Jefferson. 41 Volumes. Julian P. Boyd, ed. Princeton, NJ: Princeton University Press, 1950.

Oliver, Peter. Peter Oliver's Origin \& Progress of the American Rebellion: A Tory View. Douglass Adair \& John A. Shutz, eds. Redwood City, CA: Stanford University Press, 1961.

Schwoerer, Lois G., ed. "The Declaration of Rights." The Declaration of Rights, 1689. Baltimore, MD: John Hopkins University Press, 1981.

Tocqueville, Alexis de. Democracy in America. 2 Volumes. James T. Schleifer, ed. Indianapolis, IN: Liberty Fund, 2010.

Wilson, James. The Collected Works of James Wilson. 2 Volumes. Mark David Hall \& Kermit L. Hall, eds. Indianapolis, IN: Liberty Fund, 2007.

Secondary Sources 
Bailyn, Bernard. The Ideological Origins of the American Revolution. Cambridge, MA: Harvard University Press, 1967.

-. The Origin of American Politics. New York, NY: Knopf, 1968.

-. Sometimes an Art: Nine Essays on History. New York, NY: Knopf, 2015.

Gregg, Gary, II, ed. Vital Remnants: America's Founding and the Western Tradition.

Wilmington, DE: Intercollegiate Studies Institute Books, 1999.

------------, Mark David Hall, eds. America 's Forgotten Founders. Wilmington, DE:

Intercollegiate Studies Institute Books, 2011.

Grossman, George S. The Spirit of American Law. Boulder, CO: Westview Press, 2000.

Hall, Mark David. The Political and Legal Philosophy of James Wilson, 1742-1798. Columbia, MO: University of Missouri Press, 1997.

Kammen, Michael. Deputyes and Libertyes: The Origins of Representative Government in Colonial America. New York, NY: Knopf, 1969.

Hartog, Hendrick \& Nelson, William E., eds. Law as Culture and Culture as Law: Essays in Honor of John Phillip Reid. Madison, WI: Madison House Publishers, 2000.

Hoffer, Peter Charles. The Salem Witch Trials: A Legal History. Lawrence, KS: University Press of Kansas, 1997.

Lovejoy, David. The Glorious Revolution in America. New York, NY: Harper and Row, 1972.

Lustig, Mary Lou. The Imperial Executive in America: Sir Edmund Andros, 1637-1714. Madison, NJ: Fairleigh Dickinson, 2002.

McDonald, Forrest. Novus Ordo Seclorum: The Intellectual Origins of the Constitution. Lawrence, KS: University Press of Kansas, 1985.

Pocock, J.G.A. The Machiavellian Moment: Florentine Political Thought and the Atlantic Republic Tradition. Princeton, NJ: Princeton University Press, 1975.

Rakove, Jack N. Original Meanings: Politics and Ideas in the Making of the Constitution. New York, NY: Vintage Books, 1997.

Read, James. Power Versus Liberty: Madison, Hamilton, Wilson, and Jefferson. Charlottesville, VA: University Press of Virginia, 2000.

Reich, Jerome R. Leisler's Rebellion. Chicago, IL: University of Chicago Press, 1953. 
Reid, John Phillip. In Defiance of the Law: The Standing Army Controversy, The Two Constitutions, and the Coming of the American Revolution. Chapel Hill, NC: University of North Carolina Press, 1981.

-. The Concept of Liberty in the Age of the American Revolution. Chicago, IL: University of Chicago Press, 1988.

Constitutional History of the American Revolution: The Authority of Law. Madison, WI: University of Wisconsin Press, 1993.

Constitutional History of the American Revolution: The Authority to Legislate. Madison, WI: University of Wisconsin Press, 1991.

-. The Concept of Representation in the Age of the American Revolution, University of Chicago Press, 1989.

Sandoz, Ellis. The Roots of Liberty: Magna Carta, Ancient Constitution, and the AngloAmerican Tradition of Rule of Law. Indianapolis, IN: Liberty Fund, 2008.

Smith, Charles Page. James Wilson: Founding Father, 1742-1798. Chapel Hill, NC: University of North Carolina Press, 1956.

Wood, Gordon S. The Creation of the American Republic, 1776-1787. Chapel Hill, NC: University of North Carolina Press, 1969.

Representation in the American Revolution. Charlottesville, VA: University of Virginia Press, 2008.

\section{Scholarly Articles}

Caffee, Bradley Jay. "James Wilson: Progressive Constitutionalist.” M.A. Thesis - University of Louisville, 2003.

Clagett, Martin. "James Wilson-His Scottish Background: Corrections and Additions." Pennsylvania History: A Journal of Mid-Atlantic Studies 79 (2012): 154-176.

Gordon, Colin. "Crafting a Usable Past: Consensus, Ideology, and Historians of the American Revolution.” The William and Mary Quarterly 46 (1989): 671-695.

Green, Jack P. "Values and Society in Revolutionary America." Annals of the American Academy of Political and Social Science 426 (1976): 53-69.

Konig, David Thomas. "James Madison and Common-Law Constitutionalism." Law and History Review 28 (2010): 507-514. 
Lokken, Roy N. "The Political Theory of the American Revolution: Changing Interpretations." The History Teacher 8 (1974): 81-95.

Mathis, Doyle. “Chisholm v. Georgia: Background and Settlement.” The Journal of American History 53 (1967): 19-29.

Mullet, Charles F. “Coke and the American Revolution.” Economica 38 (1932): 457-471.

Pessen, Edward. "How Different From Each Other Were the Antebellum North and South?" The American Historical Review 85 (1980): 119-1149.

Reid, John Phillip. "In Our Contracted Sphere": The Constitutional Contract, The Stamp Act Crisis, and the Coming of the American Revolution." Columbia Law Review 76 (1976): 21-47.

Rossum, Ralph. "James Wilson and the 'Pyramid of Government:' The Federal Republic." Political Science Reviewer 6 (1976): 113-142.

Steele, Ian. "Communicating an English Revolution to the Colonies, 1688-1689," Journal of British Studies 24 (1985): 333-357.

Wood, Gordon S. "The Origin of the Bill of Rights." American Antiquarian Society 101 (1991): 255-274. 